\title{
EKSISTENSI GURU PAI DALAM MENGEMBANGKAN METODE PEMBELAJARAN PADA MASA PANDEMI COVID-19 DI SMPN 2 PRINGGASELA
}

\author{
${ }^{1}$ Susilawati, ${ }^{2}$ Azharullail, ${ }^{3}$ Hakkul Yakin \\ ${ }^{123}$ Institut Agama Islam Hamzanwadi NW Lombok Timur \\ 1E-mail: couchyuciha8@gmail.com
}

\begin{abstract}
Abstrak: Penelitian ini bertujuan, (1) Untuk mengetahui eksistensi guru PAl dalam megembangkan metode pembelajaran pada masa pandemi covid-19 (2) Untuk mengetahui metode pembelajaran yang digunakan guru PAI pada masa pendemi covid-19 (3) Untuk mengetahui kelebihan dan kekurangan metode pembelajaran yang digunakan guru PAI pada masa pandemi covid-19. Penelitian ini menggunakan pendekatan kualitatif deskriptif. Teknik pengumpulan data: wawancara, observasi, dan dokumentasi. Hasil penelitian menunjukkan bahwa guru PAI SMPN 2 Pringgasela tetap eksis melakukan proses belajar mengajar walaupun dalam keadaan pandemi Covid-19. Proses pembelajaran yang dilakukan bervariasai yaitu daring dan luring metode dengan menggunakan dua cara ini disebut metode Blended Learning, ini tergantung pada surat edaran pemerintah. Proses pembelajaran secara daring menggunakan aplikasi whatsapp dengan menggunakan metode tanya jawab. Sedangkan luring atau tatap muka ini dilakukan di sekolah secara langsung dan home visit mengunjungi rumah siswa untuk melakukan proses belajar mengajar, pembelajaran secara luring ini menggunakan metode pembelajaran modifikasi tanya jawab (modification of question and answer), mengelompokkan kartu (card gruf), metode demontrasi, ceramah, dan diskusi.
\end{abstract}

Kata Kunci: Eksistensi Guru PAl, Masa Pandemi Covid-19

Abstract: This study aims, (1) To find out the existence of PAl teachers in developing learning methods during the covid-19 pandemic (2) To find out the learning methods used by PAI teachers during the COVID-19 pandemic (3) To find Explain the advantages and disadvantages of the method learning used by PAI teachers during the covid-19 pandemic. This study uses a descriptive qualitative approach. Data collection techniques: interviews, observations, and documentation. The results showed that PAI teachers in SMPN 2 Pringgasela still exist to carry out the teaching and learning process despite the Covid-19 pandemic. The learning process carried out is different, namely online and offline methods using these two methods are called Blended Learning method, this depends on the government circular. Online learning process using WhatsApp application using question and answer method. While offline or face-to-face meetings are conducted at the school directly and home visits visit students' homes to carry out the teaching and learning process, offline learning uses a modified question and answer learning method, group card, demonstration methods, lectures, and discussions.

Keywords: Existence of PAI Teachers, Covid-19 Pandemic Period

\section{PENDAHULUAN}

pada saat ini disrupsi teknologi terjadi di dunia pendidikan, pembelajaran tatap muka yang biasanya dilaksanakan di sekolah, secara tiba-tiba mengalami perubahan yang sangat drastis. Tantangan yang dihadapi lebih menyulitkan apalagi dipedesaan 
yang kurang sinyal dan latar belakang orang tua yang kurang mampu, ini menyulitkan bagi guru dan peserta didik untuk mentransfer dan menerima ilmu pengetahuan dikarenakan adanya pandemi Covid-19 bukan hanya indonesia tetapi negara-negara di dunia juga telah dikejutkan oleh wabah penyakit mematikan yang disebabkan oleh virus yang dikenal dengan istilah Covid-19 (Thasporn Sangsawan, 2020: 283).

Penularan Covid-19 berasal dari kota Wuhan-China akhir desember 2019 yang penyebarannya berlangsung sangat cepat hanya dalam waktu beberapa bulan keberbagai negara di dunia, sehingga WHO (World Health Organization) menyebut penyebaran Covid-19 ini sebagai sebuah pandemi (Mailizar, 2020: 1). Akibat dari pandemi Covid-19 ini, menyebabkan diterapkannya berbagai kebijakan untuk memutus mata rantai penyebaran virus Covid-19 di indonesia. Upaya yang dilakukan oleh pemerintah di indonesia salah satunya dengan menerapkan himbauan kepada masyarakat agar melakukan physical distancing yaitu himbauan untuk menjaga jarak diantara masyarakat, menjauhi aktivitas dalam segala bentuk kerumunan, perkumpulan, dan menghindari adanya pertemuan yang melibatkan banyak orang. Upaya tersebut ditujukan kepada masyarakat agar dapat dilakukan untuk memutus rantai penyebaran pandemi Covid-19 yang terjadi saat ini (Matdio Sihaan, 2020: 2).

Pandemi Covid-19 memberikan dampak pada banyak pihak, kondisi ini sudah merambah pada dunia pendidikan, pemerintah pusat sampai pada tingkat daerah memberikan kebijakan untuk meliburkan seluruh lembaga pendidikan. Hal ini dilakukan sebagai upaya mencegah meluasnya penularan Covid-19. Diharapkan dengan seluruh lembaga pendidikan tidak melaksanakan aktivitas seperti biasanya, hal ini dapat meminimalisir menyebarnya penyakit Covid-19 ini. Hal serupa juga sudah dilakukan oleh berbagai negara yang terpapar penyakit Covid-19 ini. Kebijakan lockdown atau karantina dilakukan sebagai upaya mengurangi interaksi banyak orang yang dapat memberi akses pada penyebaran virus corona. Kebijakan yang diambil oleh banyak negara termasuk indonesia dengan meliburkan seluruh aktivitas pendidikan, membuat pemerintah dan lembaga terkait harus menghadirkan alternatif proses pendidikan bagi peserta didik maupun mahasiswa yang tidak bisa melaksanakan proses pendidikan pada lembaga pendidikan (Andri Anugrahana, 2020: 282).

Pemerintah menerapkan kebijakan yaitu Work From Home (WFH). Kebijakan ini merupakan upaya yang diterapkan kepada masyarakat agar dapat menyelesaikan 
segala pekerjaan di rumah. Pendidikan di indonesia pun menjadi salah satu bidang yang terdampak akibat adanya pandemi Covid-19 tersebut. Dengan adanya pembatasan interaksi, kementerian pendidikan di indonesia juga mengeluarkan kebijakan yaitu dengan meliburkan sekolah dan mengganti proses kegiatan belajar mengajar dengan menggunakan sistem dalam jaringan (daring). Dengan menggunakan sistem pembelajaran secara daring ini, terkadang muncul berbagai masalah yang dihadapi oleh siswa dan guru, seperti materi pelajaran yang belum selesai disampaikan oleh guru kemudian guru mengganti dengan tugas lainnya. Hal tersebut menjadi keluhan bagi siswa karena tugas yang diberikan oleh guru lebih banyak (Matdio Sihaan, 2020: 2).

Permasalahan lain dari adanya sistem pembelajaran secara online ini adalah akses informasi yang terkendala oleh sinyal yang menyebabkan lambatnya dalam mengakses informasi. Siswa terkadang tertinggal dengan informasi akibat dari sinyal yang kurang memadai. Akibatnya mereka terlambat dalam mengumpulkan suatu tugas yang diberikan oleh guru. Belum lagi bagi guru yang memeriksa banyak tugas yang telah diberikan kepada siswa, membuat ruang penyimpanan gadget semakin terbatas. Penerapan pembelajaran online juga membuat pendidik berpikir kembali, mengenai model dan metode pembelajaran yang akan digunakan. Yang awalnya seorang guru sudah mempersiapkan model pembelajaran yang akan digunakan, kemudian harus mengubah model pembelajaran tersebut (Matdio Sihaan, 2020: 3).

Berdasarkan observasi awal peneliti menemukan bahwa guru PAI di SMPN 2 Pringgasela juga ikut merasakan tantangan yang sangat luar biasa pada sektor pendidikan yang dihadapi akibat pandemi Covid-19 yang dimana mengharuskan guru untuk menentukan metode pembelajaraan, karena metode menempati peranan yang tidak kalah penting dari komponen lainnya dalam kegiatan belajar mengajar. Tidak ada satu pun kegiatan belajar mengajar yang tidak menggunakan metode pengajaran, tentunya metode yang digunakan sebelum masa pandemi Covid-19 harus dikembangkan karena proses pembelajaran pada masa pandemi Covid-19 lebih menyulitkan dan lebih menantang.

\section{METODELOGI PENELITIAN}

Penelitian ini mengunakan jenis penelitian kualitatif deskriftif, jenis penelitian kualitatif deskriptif yaitu menganalisis dan menyajikan fakta-fakta secara sistematik sehingga dapat lebih mudah dipahami dan disimpulkan yang bertujuan agar 
penulis dapat mengetahui dan menggambarkan apa saja yang terjadi di lapangan dengan jelas dan terperinci, sehingga nantinya penulis dapat menggambarkan serta mengumpulkan data mengenai eksistensi guru PAl dalam megembangkan metode pembelajaran pada pasa pendemi Covid-19 di SMPN 2 Pringgasela.

Penelitian ini menggunakan beberapa teknik dalam pengumpulannya. Dengan harapan data yang diperoleh lebih valid. Untuk memperoleh data yang valid, maka teknik pengumpulan data yang digunakan dalam penelitian kualitatif ini yaitu: wawancara, Observasi, dan Dokumentasi.

\section{HASIL DAN PEMBAHASAN}

\section{Eksistensi Guru PAI Dalam Megembagkan Metode Pembelajaran Pada Masa Pandemi Covid-19 di SMPN 2 Pringgasela}

Berdasarkan hasil penelitian yang peneliti lakukan di lapangan bahwa guru PAI SMPN 2 Pringgasela tetap eksis dalam melakukan pembelajaran meskipun proses belajar mengajar dilakukan pada masa pandemi Covid-19 yang dimana proses pembelajarannya lebih menyulitkan, meskipun demikian guru PAI di SMPN 2 Pringgasela tetap berusaha melakukan proses belajar mengajar dengan baik, adapun guru SMPN 2 Pringgasela melakukan pembelajaran selama pandemi Covid-19 ini dengan dua cara yaitu online/daring dan offline/luring metode dengan menggunakan dua cara ini disebut dengan metode Blended Learning.

Pembelajaran yang dilakukan secara online atau daring "dalam jaringan" dilakukan melalui aplikasi whatsapp karena aplikasi inilah yang dianggap paling mudah diakses untuk berkomunikasi, menyampaikan materi, dan menerima tugas dari peserta didik. Adapun pembelajaran secara offline atau luring "luar jaringan" dilakukan dengan dua cara yakni belajar disekolah secara langsung dengan waktu yang terbatas dan home visit dilakukan dengan mendatangi rumah-rumah siswa untuk melangsungkan proses belajar mengajar.

Eksistensi guru PAI SMPN 2 Pringgasela dalam mengembangkan metode pembelajaran pada masa pandemi Covid-19 ialah proses belajar mengajar dilakukan dengan bervariasi, melangsungkan pembelajaran secara online/daring menjadi pilihan guru untuk menunjang tetap berjalannya proses belajar mengajar selama pandemi Covid-19. Adapun pada proses pembelajaran pada masa pandemi Covid-19 yang dilakukan secara tatap muka yaitu dilakukan dengan 
dua cara melangsungkan pembelajaran di sekolah dengan waktu yang sangat terbatas dengan tetap taat protokol kesehatan dan mengunjugi rumah-rumah siswa untuk melakukan proses belajar mengajar (home visit). Sebagaimana jawaban guru PAI SMPN 2 Pringgasela ketika diwawancarai mengenai bagaimana proses pembelajaran selama pandemi:

"Untuk proses pembelajaran selama masa pandemi Covid-19 tetap berjalan dengan baik, hanya saja pembelajaran tatap muka agak terbatas dan kontrol guru juga ikut terbatas apalagi saat pembelajaran online, kami sebagai guru tidak sepenuhnya dapat mengontrol siswa, butuh juga bantuan orang tua para murid untuk mengontrol pembelajaran anak"(wawancara dengan Asroruddin, 12/08/2021).

Berdasarkan hasil wawancara dengan guru memang pembelajaran secara tatap muka sangat terbatas hal ini dilakukan untuk menghindari berintraksi dengan banyak orang agar dapat memutuskan penyebaran Covid-19. Sejalan dengan hasil wawancara dengan guru yang bersangkutan, kepala sekoalah mengungkapkan:

"Kami berpedoman pada aturan yang ada, surat bupati, surat edaran pemerintah kalau dianjurkan belajar dirumah iya belajar dirumah kalau belajar tatap muka iya belajar secara tatap muka, tetapi belajar tatap muka ini kami lakukan dengan tatap menaati protokol kesehatan" (Wawancara dengan Slamet Riyadi, 08/08/2021).

Sejalan dengan hasil observasi yang dilakukan penulis pada hari rabu tanggal 28 juli 2021 penulis menemukan anak-anak yang bersekolah saat itu harus dicek menggunakan alat pengukur suhu badan di depan pintu masuk sekolah oleh satpam sekolah SMPN 2 Pringgasela kemudian peserta didik mencuci tangan di tempat yang sudah disediakan. Perserta didik yang bersekolah juga diwajibkan menggunakan masker sehingga saya tidak mendapati anak yang bersekolah tidak menggunakan masker.

Berdasarkan hasil wawancara dengan guru PAI ketika ditanya dengan pertanyaan " bagaimana eksistensi/keberadaan bapak sebagai guru PAI dalam mengembangkan metode pembelajaran pada masa pandemi Covid-19 di smpn 2 priggasela.

"Eksistensi saya sebagai guru PAI dalam mengembangkan metode pembelajaran selama pandemi Covid-19 tidak jauh beda dengan pelajaran yang lain, dimana saya sebagai guru PAI di SMPN 2 Pringgasela lebih banyak mengedepankan pembinaan tentang keyakinan, agar peserta didik lebih yakin bahwa segala sesuatu itu sudah ada yang mengatur, termasuk 
apa yang terjadi saat ini yaitu keberadaan Covid-19. Jadi intinya jangan sampai anak didik itu lebih yakin dengan corona ketimbang yang membuat corona. Dengan demikian, dengan didampingi oleh guru PAI setidaknya peserta didik paham dengan takdir" (Wawancara dengan Asroruddin, 12/08/2021).

Hasil observasi saya pada saat proses belajar dilakukan di rumah, siswa dalam proses belajar mengajar dibagi menjadi kelompok-kelompok kecil sesuai dengan kelas dan daerah masing-masing, kemudian ditentukan hari dimana guru akan datang menggunjungi siswa untuk belajar. Untuk pembelajaran ini tetap menerapkan protokol kesehatan. Peneliti juga menemukan siswa yang tidak memiliki hand phone (HP) android dan juga siswa ini tidak memilliki teman kelas di daerahnya siswa ini disuruh untuk datang ke sekolah setiap hari senin dan hari jum'at kemudian diberikan tugas sesuai dengan jam pelajaran pada saat PPKM (pemberlakuan pembatasan kegiatan masyarakat) berlangsung.

\section{Metode Pembelajaran Yang Digunakan Guru PAl Pada Masa Pandemi Covid-19 di SMPN 2 Pringgasela}

Berdasarkan temuan peneliti di lapangan bahwa pembelajaran selama pandemi Covid-19 di SMPN 2 Pringgasela proses pembelajaran yang dilakukan bervariasai yaitu online/daring dan offline/luring metode dengan menggunakan dua cara ini disebut metode Blended Learning, ini tergantung pada surat edaran pemerintah. proses pembelajaran secara online/daring menggunakan aplikasi whatsaap dengan menggunakan metode tanya jawab. Sedangkan offline/luring atau tatap muka ini dilakukan di sekolah secara langsung dan home visit mengunjungi rumah siswa untuk melakukan proses belajar mengajar, pembelajaran secara offline/luring ini menggunakan metode pembelajaran modifikasi tanya jawab (modification of question and answer), mengelompokkan kartu (card gruf), metode demontrasi, ceramah, dan diskusi.

Proses pembelajaran yang dilakukan selama pandemi Covid-19 di SMPN 2 Pringgasela dengan online/daring dan offline/luring ini tergantung pada surat edaran pemerintah, sejalan dengan hasil wawancara dengan guru yang bersangkutan, ketika ditanya dengan pertanyaan "metode apa saja yang digunakan untuk mengajar selama pandemi Covid-19":

"Metode yang sering saya gunakan itu, metode tanya jawab, diskusi , ceramah, metode yang saya gunakan itu bervariasi, selama pandemi ini 
kan kadang pembelajarannya daring kadang tatap muka, ya itu kalau daring saya menggunakan media sosial wahatsapp, pernah juga kita melakukan home visit" (Wawancara dengan Asroruddin, 12/08/2021).

Sejalan dengan hasil observasi pembelajaran yang dilakukan guru PAI selama pandemi Covid-19 ini guru menggunakan pembelajaran daring dan juga luring. Hal ini membuat pengawasan belajar ada pada peserta didik, karena kontrol dari guru tidak bisa sepenuhnya. Ini dikarenakan daya serap belajar peserta didik itu berbeda-beda apalagi pada saat pembelajaran daring kontrol pengawasan itu sepenuhnya pada siswa, saat pembelajaran luringpun waktunya dibatasi tidak seperti pembelajaran yang dilakukan sebelum indosesia dilanda Covid-19.

Berdasarkan hasil wawancara dan dokumentasi di SMPN 2 Pringgasela tentang proses pembelajaran dimasa pandemi Covid-19 ada beberapa proses pembelajran yang diberlakukan sesuai dengan kondisi dan juga surat edaran dari pemerintah:

a. Pembelajaran Daring Menggunakan Aplikasi Whatsapp Menggunakan Metode Tanya Jawab

Bekerja dari rumah atau work from home (WFH) adalah bentuk imbauan pemerintah dalam rangka menghentikan penyebaran pandemi Covid-19. Imbauan ini juga berlaku pada SMPN 2 Pringgasela sekolah ini menerapkan belajar dari rumah secara daring atau online.

Prores pembelajaran daring dilakukan bagi siswa yang memiliki perangkat teknologi informasi komunikasi dan tinggal di daerah yang jaringan internet baik, pembelajaran daring diterapkan melalui aplikasi whatsapp, dikarenakan whatsapplah yang paling efektif digunakan di dalam proses pembelajaran daring, karena lebih mudah di akses oleh guru maupun siswa.

Pembelajaran menggunakan sistem daring (online) tetap dikontrol guru sehingga pembelajaran dapat berjalan dengan lancar, guru yang bersangkutan menambahkan "yaa untuk membuat pembelajran berjalan secara sistematis saya membuat RPP, supaya bisa mewujudkan tujuan yang diharapkan saya membuat rencana pelaksanaan pembelajaran daring" (Wawancara dengan Asroruddin, 12/08/2021)

Peryataan di atas diperkuat dengan adanya dokumentasi tertulis yang tertera dalam RPP kelas IX semester ganjil sebagai berikut: 
Tabel 1

Rencana Pelaksanaan Pembelajaran Daring

\section{Rencana Pelaksanaan Pembelajaran Daring}

Satuan Pendidikan : SMPN 2 Pringgasela

Mata Pelajaran : Pendidikan Agama Islam

Kelas/Semester : : IX/I

Materi : Iman Kepada Hari Akhir

Tahun Pelajaran : 2021/2022

Waktu : 3 Pertemuan

\section{A. Tujuan pembelajaran}

Melalui pembelajaran daring melalui aplikasi whatsapp dan media pembelajaran berbasis aplikasi android, peserta didik dapat:

1. Pertemuan pertama

* Mendeskripsikan pengertian hari akhir.

* Mendeskripsikan pengertian iman kepada hari akhir dengan benar.

* Menunjukkan dalil iman kepada hari akhir dengan benar.

* Menyebutkan macam-macam kiamat dengan benar.

* Menjelaskan nama lain hari akhir.

* Menjaskan tanda-tanda kiamat.

2. Pertemuan kedua

* Menjelaskan proses kejadian kiamat kubra dengan benar

* Menjelaskan urutan pristiwa di alam akhirat.

* Menjelaskan hikmah beriman kepada hari akhir.

3. Pertemuan ketiga

* Membaca dalil naqli yang menjalakan gambaran kejadian hari akhir.

B. Langkah-langkah pembelajran

1. Pendahuluan

a. Guru membuat whatsapp gruf sebagai media komunikasi

b. Guru menyampaikan tujuan pembelajaran, scnario pembelajaran, dan aspek-aspek yang dinilai.

2. Kegiatan inti

\section{Pertemuan pertama}

a. Siswa mengunduh aplikasi media pembelajaran interaktif materi tentang iman kepada hari akhir lewat link https ://bit.ly/mediaPAl-smp-s1 aplikasi: $\underline{P A l}$ 9.1.1

b. Guru meminta peserta didik membaca materi yang sudah ada dalam aplikasi.

c. Siswa yang menemui masalah atau kendala kaitannya dengan materi langsung bisa bertanya lewat gruf WA yang sudah dibuat oleh guru.

d. Guru menanyakan penguasaan siswa lewat WA gruf kaitannya dengan materi yang telah mereka pelajari melalui aplikasi media pembelajaran inreaktif di android mereke.

e. Peserta didik dan guru berdiskusi melalui WA gruf.

Pertemuan kedua

a. Siswa melanjutkan matri pembahasan melalui aplikasi media pembelajaran interaktif yang sudah diunduh pada pertemuan 
pertama.

b. Siswa yang menemui kendala atau masalah yang kaitannya dengan materi langsung bisa bertanya bertanya lewat WA gruf yang sudah dibuat oleh guru .

c. Guru menanyakan penguasaan siswa lewat WA gruf kaitannya dengan matri yang telah mereka pelajarai melalui aplikasi media pembelajaran intraktif di android mereka.

d. Peserta didik dan guru bertanya memali whatsapp gruf.

\section{Pertemuan ketiga}

a. Siswa melanjutkan materi pembahasan melalui aplikasi media pembelajran interaktif yang sudah di unduh pada pertemuan pertama.

b. Siswa yang menemui kendala atau masalah yang kaitannya dengan materi langsung bisa bertanya bertanya lewat WA gruf yang sudah dibuat oleh guru.

c. Guru menanyakan penguasaan siswa lewat WA gruf kaitannya dengan materi yang telah mereka pelajari melalui aplikasi media pembelajaran intraktif di android mereka.

d. Siswa berlatih menjawab yang sudah disediakan lewat aplikasi yang sudah di unduh secara mandiri dalam bentuk pilihan ganda.

e. Peserta didik mengerjakan tes akhir memalui google from lewat link.

2. Penutup
a. Guru mrnyimpulkan materi yang telah dipelajarai, mengapresiasi dan tindak lanjut.
b. Guru menutup pembelajaran dengan mengucapkan salam.

C. Penilaian

1. Sikap

Teknik penilain : Pengamatan, penilaian diri

Instrumen

: Lembar pengamatan selama daring dan lembar penilain diri yang memuat aspek syukur, peduli, tanggung jawab, disiplin, saling menghormati, dan

2. Pengetahuan menghargai.

Teknik penilain : Tes tertulis / pilihan ganda

3. Keterampilan

Teknik penilain : Penilain kinerja, keaktifan, kemampuan bertabya dan menjawab, kemampuan memberikan saran/

Sukatain, 13 Juli 2021 masukan pada gruf wa.

\begin{tabular}{cc} 
Kepala Sekolah & Guru Bidang Studi \\
Nlamet Riyadi, S.Pd.Pkn & Asroruddin, S.Pd.i \\
\hline
\end{tabular}

(Sumber: Guru PAI kelas IX SMPN 2 Pringgasela, dokumentasi RPP daring tahun 2021)

Pembelajaran daring dilakukan melalui aplikasi whatsapp dengan metode tanya jawab dimana guru meminta siswa untuk mengunduh aplikasi 
media pembelajaran interaktif dan mengunduh materi yang akan dipelajari melalui link https ://bit.ly/media-PAI-smp-s1 aplikasi: PAI 9.1.1 kemudian materi itu yang akan dibahas di whatsapp grup sampai siswa benar-benar memahami materi yang dipelajari.

b. Pembelajaran Luring (Luar Jaringan)

Pembelajaran luring juga dilakukan oleh guru PAI kelas IX SMPN 2 Pringgasela akan tetapi waktunya terbatas dan juga pembelajaran tatap muka ini menerapkan protokol kesehatan hal ini dibuktikan dengan adanya dokumen tertulis.

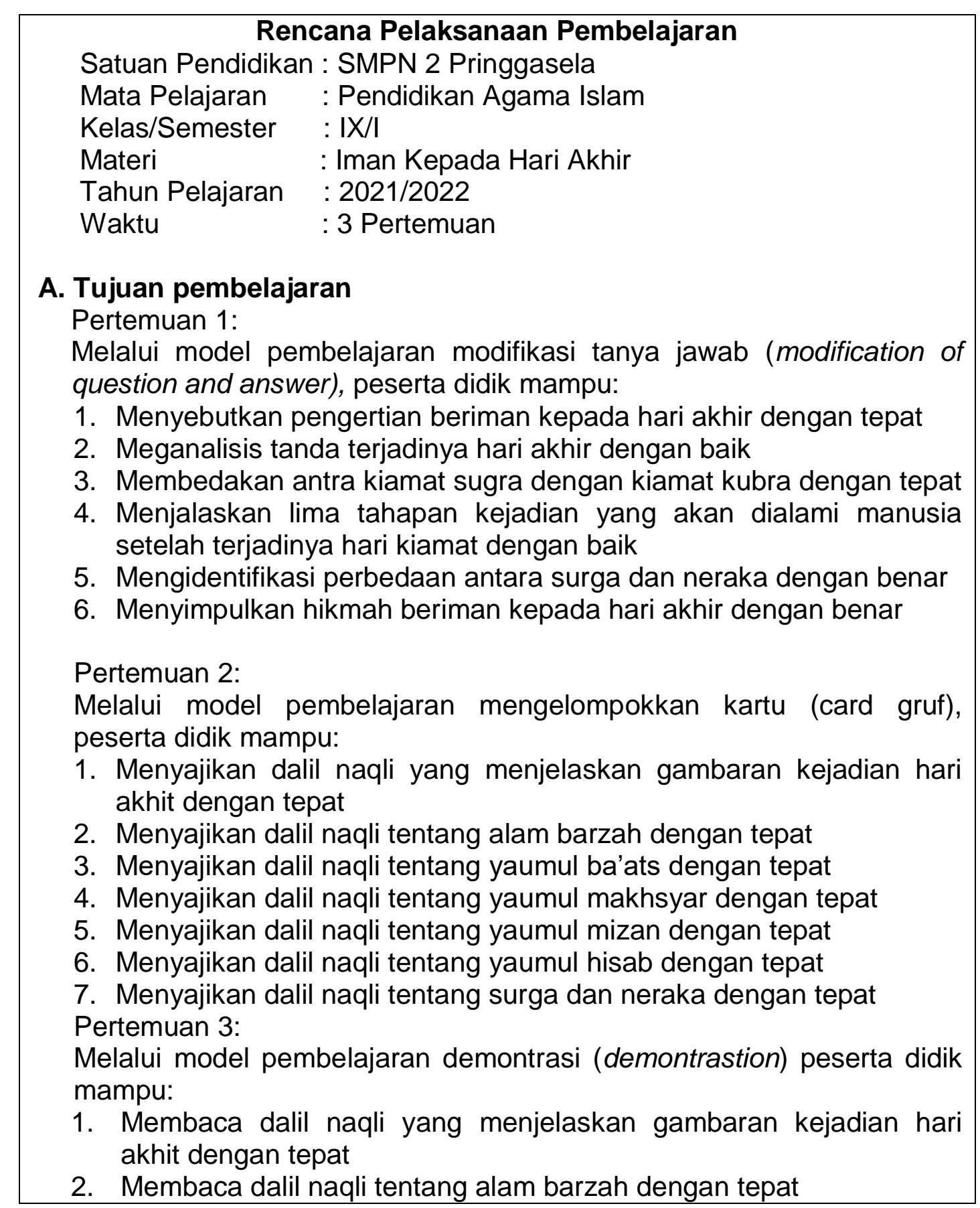


3. Membaca dalil naqli tentang yaumul ba'ats dengan tepat

4. Membaca dalil naqli tentang yaumul makhsyar dengan tepat

5. Membaca dalil naqli tentang yaumul mizan dengan tepat

6. Membaca dalil naqli tentang yaumul hisab dengan tepat

7. Membaca dalil naqli tentang surga dan neraka dengan tepat

\section{B. Langkah-langkah (kegiatan) pembelajran}

\section{a. Kegiatan pendahuluan}

1) Membuka pembelajran dengan memacap salam, dilanjutkan salah seorang peserta didik memimpin doa akan belajar dan membaca al-qur'an surah pilihan.

2) Melakukan appersepsi dan motovasi peserta didik pentingnya mempelajari materi beriman kepada hari akhir.

3) MenyamPAlkan kompetensi dasar, tujuan pembelajaran, dan tahapan kegiatan yang akan dilaksanakan dalam pembelajaran.

4) Mengadakan tes awal (pretest)

b. Kegiatan inti

\section{Pertemuan 1:}

1) Pembagian lima kelompok.

2) Setiap kelompok mendapatkan teks bacaan tentang beriman kepada hari akhir, satu kertas plano dan satu spidol.

3) Setiap kelompok mengamati teks bacaan tentang beriman kepada hari akhir.

4) Setiap kelompok membuat 10 pwrtanyaan tentang beriman kepada hari akhir, ditulis di kertas plano dengan memakai sepidol.

5) Setiap kelompok saling bertukar 10 pertanyaan yang ditulis dalam kertas plano.

6) Setiap kelompok menjawab 10 pertanyaan yang ditulis dalam kertas plno.

7) Setelah menjawabnya, setiap kelompok mengembalikan kertas plno ke kempok asal.

8) Kelompok asal mengecek dan memberi skor terhadap jawaban dari kelompok yang menjawab.

9) Presentasi tiap kelompok dan kelompok lain memperhatikan serta menganggapinya.

Pertemuan 2:

1) Pembagian lima kelompok.

2) Guru menyiapkan paket kartu untuk lima kelompok yang membuat tentang juduk dan dalil naqli gambaran hari kiamat serta tahapan-tahapannya.

3) Setiap kelompok mendapatkan satu paker kartu dan teks bacaan tentang dalil naqli yang menjelaskan gambaran hari kiamat dan tahapan-tahapannya.

4) Setiap kelompok mengamati bacaan teks tentang dali naqli yang menjelaskan gambaran hari kiamat dan tahapantahapannya.

5) Dengan melihat teks bacaan, setiap kelompok memasangkan kartu-kartu tersebut berdasarkan judul dan dalil naqli yang termasuk ke dalamnya. 
6) Tampa melihat teks bacaan, setiap kelompok memasangkan kartu-kartu tersebut berdasarkan dalil naqli yang termasuk kedalamnya.

7) Pemberian penghargaan atau reward kepada kelompok yang tercepat dan paling tepat dalam memasangkan judul kartu dan dalil naqlinya.

8) Persentasi tiap kelompok, kelompok lain memperhatikan dan menaggapi

\section{Pertemuan 3:}

1) Guru menyampaikan komptensi yang ingin dicaai

2) Guru menyajikan sekilas materi yang akan diampaikan

3) Menyiapkan bahan atau alat yang diperlukan

4) Menunjuk salah seorang peserta didik untuk mendemontrasikan bacaab dalil naqli tentang hari kiamat.

5) Seluruh pesrta didik memperhatikan demontrasi dan menganalisisnya.

6) Tiap peserta didik mengemukakan hasil analisisnya dan juga pengalaman peserta didik didemontrasikan

7) Guru membuat kesimpulan

\section{c. Kegiatan penutup}

1) Pemberikan penguatan dan kesimpulan materi tentang beriman kepada hari akhir.

2) Pesrta didik bersama guru melakukan refleksi terhadap pembelajran yang telah dilaksanakan.

3) Pesrta didik mengungkapkan pesan moral yang diproleh dari pembelajaran.

4) Pesrta didik mengerjakan tes akhir (posttest)

5) Penyampaikan rencana kegiatan pertemuan berikutnya.

6) Pesrta didik dan guru bersma-sama menutup pelajaran dengan berdo'a.

\section{Penilaian pembelajaran}

1. Sikap spritual: teknik penilaian: penilaian diri; bentuk instrumen: lembar penilaian diri

2. Sikap sosial: teknik penilaian: observasi; bentuk instrumen: jurnal.

3. Pengetahuan: teknik penilaian: tes tertulis; bentuk instrumen: lembarab tes tertulis.

4. Keterampilan: teknik penilaian: kinarja; bentuk instrumen: lembar penlain kinarja.

Sukatain, 2021

Kepala Sekolah

Slamet Riyadi, S.Pd.Pkn NIP: 196505081991031018
Guru Mata Pelajarn PAI Dan Budi Pekerti Asroruddin, S.Pd.I

(Sumber: guru PAI kelas IX SMPN 2 Pringgasela, dokumentasi RPP tahun 2021)

Home visit dilakukan dengan cara tatap muka. Pembelajaran tatap muka ini dilakukan tidak di sekolah seperti biasa, melainkan dilakukan di 
rumah-rumah siswa dengan cara guru berkunjung ke rumah siswa tersebut. Pembelajaran dilakukan dengan syarat tetap memenuhi protokol kesehatan dengan menjaga jarak, mengumpulkan siswa sesuai kelompok dengan jumlah 8-10 orang, menyediakan wadah tempat cuci tangan, menggunakan masker, mengatur jarak tempat duduk dengan jarak minimal 1 meter.

Pembelajaran yang dilakukan dengan home visit ini adalah dengan cara mengunjungi rumah siswa secara bergiliran sesuai kelompok. Sedangkan, jadwal dan waktu pelaksanaan pembelajaran dilakukan dengan cara membagi hari dan waktu pelaksanaan. Dalam 1 hari proses pembelajaran dilakukan untuk 1 kelompok dengan durasi waktu 25-30 menit. Pandemi Covid-19 masih melanda berbagai cara untuk menciptakan ruang belajarpun dilakukan oleh SMPN 2 Pringgasela salah satunya ialah home visit ini sejalan dengan hasil wawancara dengan murid:

"Bermacam-macam cara pembelajaran yang pernah dilakukan pak guru mengajari kita selama pandemi covid 19 ini, penah belajar online, pernah juga kita diajar dengan cara pak guru mendatangi rumah kita, kadang juga kita kumpul buat kelompok belajar terus pak guru mengajari kami di rumah sesuai kelompok belajar, terus kami disuruh tetap taat protokol kesehatan. Kadang juga kita pergi ke sekolah untuk mengembil tugas kemudia kita kerjakan dirumah" (Wawancara dengan Febby Ikhwan Utami, 31/08/2021)

\section{Kelebihan dan Kekurangan Metode Pembelajaran Yang Digunakan Guru PAI Pada Masa Pendemi Covid-19 Di SMPN 2 Pringgasela}

Berdasarkan hasil penelitian yang peneliti lakukan di SMPN 2 Pringgasela peneliti dapat mengemukakan tantang kelebihan dan kekurang dari metode pembelajaran yang digunakan guru PAI kelas IX selama pandemi Covid-19 di SMPN 2 Pringgassela diantaranya sebagai berikut. Kelebihan pembelajaran online yaitu para siswa dapat mengikuti pembelajaran kapan pun dan dimana pun sesuai keinginan dan memiliki koneksi internet dengan baik, siswa dapat melihat kembali materi pembelajaran karena materi yang diberikan guru, melatih siswa untuk belajar mandiri sehingga pengetahuannya lebih luas, dapat menghemat biaya transportasi karena tidak perlu pergi ke sekolah, siswa memiliki banyak kesempatan bertanya karena saat pembelajaran virtual poin penilaian termasuk keaktifan siswa.

Pembelajaran daring yang dilakukan guru PAl dapat memberikan pembelajaran kepada siswa walapun jarak jauh dan tidak harus bertemu dengan 
siswa untuk mentranfer ilmu pengetahun yang akan diajarakan sejalan dengan hasil wawancara dengan guru yang bersangkutan "kelebihan menggunakan media online itu bisa mentranfer ilmu pengrtahuan tampa harus berjumpa, bertatap muka dengan murid iya ini sangat membantu pada saat ini (saat pandemi Covid-19)" (Wawancara dengan Asroruddin, 22/08/2021).

Kelemahnnya berdasarkan wawancara dengan guru yang bersangkutan menambahkan:

"Media onine itu menurut saya jak kelemannnya yang banyak, terutama pada penerapan etika, tidak bisa dikontrol, kadang grup wanya digukan untuk main-main siswa juga tidak semunya memiliki hp jadinya dia tidak dapat mengikuti kelas online solusinya iya diberikan tugas dititipkan oleh teman kelasnya kemudian di antar ke sekolah" (Wawancara dengan Asroruddin, 22/08/2021).

Peserta didik juga lebih menyukai pembelajran secara langsung tatap muka dari pada membelajaran online ini sejalan dengan hasil wawancara penulis dengan salah satu murid dari SMPN 2 Pringgasela ia mengungkapkan:

"Saya jauh lebih senang belajar secara langsung, awal-awalnya jak iya kami senang belajar online soalnya lebih banyak waktu dirumah, tetapi lama-lama kami bosan apalagi tugas yang dibrikan setiap mata pelajaran pasti ada tugasnya makanya, belajar tatap muka lebih seru bisa belajar bersama temanteman" (Wawancara dengan Febby Ikhwan Utami, 31/08/2021)

Pembelajaran tatap muka yang dilakukan pada masa pandemi Covid-19 sangatlah terbatas peserta didik juga lebih menyukai pembelajran yang dilakukan secara Inagsung tatap muka dari pada pembelajaran online ini juga merupakan kelebihan dari pembelajaran tatap muka/luring. Kekurangannya iya melakukan pembelajaran pada saat pandemi Covid-19 ini lumayan beresiko menambah akses penyebaran Covid-19, maka dari pada itu pembelajran secara tatap muka hasus dilakukan dengan protokol kesehatan yang ketat.

Home Visit juga pernah dilakukan sekolah untuk menunjang agar tidak ketertingalan pelajaran selama pandemi Covid-19. Metode ini juga memiliki kelebihan dan kekurangan. Kebihannya siswa tidak perlu kesekolah untuk belajar, tapi guru yang mendatangi peserta didik untuk belajar. Adapun kekurangannya sebagaimana diungkapkan oleh guru yang bersangnkutan: "Kita juga pernah melakukan home visit ada peserta didik yang saya datangi rumahnya untuk belajar tetapi gerbangnya masih tutup kata tetangganya dia sedang bantu orang tuanya bekerja ini juga kelemahannya sebernya untuk 
pembeljaran home visit ini" (Wawancara dengan Asroruddin, 22/08/2021)

\section{SIMPULAN}

Guru PAI SMPN 2 Pringgasela tetap eksis melakukan proses belajar mengajar walaupun dalam keadaan pandemi Covid-19. Proses pembelajaran yang dilakukan bervariasai yaitu online/daring dan offline/luring metode dengan menggunakan dua cara ini disebut metode Blended Learning, ini tergantung pada surat edaran pemerintah. proses pembelajaran secara online/daring menggunakan aplikasi whatsapp dengan menggunakan metode tanya jawab. Sedangkan ofline/luring atau tatap muka ini dilakukan di sekolah secara langsung dan home visit mengunjungi rumah siswa untuk melakukan proses belajar mengajar, pembelajaran secara ofline/luring ini menggunakan metode pembelajaran modifikasi tanya jawab (modification of question and answer), mengelompokkan kartu (card gruf), metode demontrasi, ceramah, dan diskusi. setiap metode pembelajaran yang digunakan pasti memiliki kelebihan dan kekurangan begitu juga dengan metode pembelajaran yang digunakan guru PAI di SMPN 2 Pringgasela.

\section{DAFTAR PUSTAKA}

Abidib, Z., Rumansyah. \& Arizona. K. (2020). "Pembelajaran Online Berbasis Proyek Salah Satu Solusi Kegiatan Belajar Mengajar Di Tengah Pandemi Covid-19", Jurnal IImiah Profesi Pendidikan, 5 (1) : 64-70.

Anggito, A \& Setiawan. J. (2018). Metodelogi Penelitian Kualitatif. Jawa Barat: CV Jejak.

Anugrahana, A. (2020). Hambatan, Solusi dan Harapan: Pembelajaran Daring Selama Masa Pandemi Covid-19 Oleh Guru Sekolah Dasar. Jurnal Pendidikan Dan Kebudayaan, 10 (3): 282-289.

Aqib, Z. (2015). Manajemen Lembaga Pendidikan Islam. Bandung: PT Sarana Tutorial Nurani Sejahtra.

Asmuni, (2020). Problematika Pembelajaran Daring Di Masa Pandemi Covid-19 Dan Solusi Pemecahannya. Jurnal Penelitian Dan Pengembangan Pendidikan, $7(4): 281-288$.

Atsani, L. G. M. Z. (2020). Transformasi Media Pembelajaran Pada Masa Pendemi Covid-19. Jurnal Studi Islam, 1(1): 82-93. 
Brahma, I. A. (2020). "Penggunaan Zoom Sebagai Pembelajaran Berbasis Online Dalam Mata Kuliah Sosiologi Dan Antropologi Pada Mahasiswa Ppkn Di Stip Kusumanegara Jakarta”, Jurnal IImu Pendidikan Nonformal, 6 (2): 97-102.

Djamarah, S. B \& Zein. A. (2018). Strategi Belajar Mengajar.rev.ed.; Jakarta: Rineka.

Echols, J. M \& Shadily. H. (2005). An English Indonesia Dictonary/Kamus Inggris Indonesia. Jakarta: PT Gramedia Pustaka Utama.

Fadlilah, A. N. (2020). Strategi Menghidupkan Motivasi Belajar Anak Usia Dini Selama Masa Pandemi Covid 19 Melalui Publikasi, Jurnal Pendidikan Anak Usia Dini. 5(1), 2020: 373-384.

Ismail. (2015). Peningkatan Kompetensi Pedagogik Guru PAI Dalam Pembelajaran, Jurnal Mudarrisuna, 4(2): 704-719

Mailizar.et.al., (2020). "Secondary School Mathematics Teachers's Views On ELearning Implementation Barriers During The Covid-19 Pandemic: The Case Of Indonesia", Eurasia Journal, 16(7) : 1-10.

Maulana, A . et al. (2010). Kamus Ilmiyah Populer Lengkap. Yogyakarta: Absolut.

Nadeak, B. (2020). The effectiveness of distance learning using social Imedia during the pandemic period of covid-19: a case in uki, international ljournal of advanced and technology, 29(7). 1764-1772.

Putra, N. (2013). Metode Penelitian Kualitatif. Jakarta : Rajawali Pers.

Rochman, A., Sidik. A. \& Nazihah.N. (2018). Perancangan Sistem Informasi Administrasi Pembayaran Spp Siswa Berbasis Web Di Smk Al-Amanah, Jurnal Sisfotek Global. 8(1) : 51-56

Sahidillah, M . W Dan Prarastro M, “Whatsapp Sebagai Media Literasi Digital Siswa”, Varia Pendidikan, 31 (1) $2019: 52$

Sangsawang, T. (2020). "An Instructional Design For Online Learning In Vocational Educational Education According To A Self-Regulated Learning Framework For Problem Solving During The Covid-19 Crisis", Indonesia Journal Of Science And Technology, 5 (2) : 283.

Siahaya, A \& Ambarita. J. (2021). Eksistensi Guru Pendidikan Agama Kristen Dalam Pembelajaran Di Tengah Pandemi Covid 19, Jurnal Penelitian Pendidikan Agama Dan Keagamaan.19(1): 67-84.

Sihaan, M. (2020). Dampak Covid-19 Terhadap Dunia Pendidikan, Jurnal Kajian IImiyah (Jki), Edisi Khusus (1): 1-6. 
Siregar, M. Y. (2020).Strategi Guru Dalam Meningkatkan Kualitas Mengajar Selama Masa Pandemi Covid-19, Jurnal Pendidikan, Sosial, dan Kebudayaan.12(2) : 180-188.

Sopian, A. (2016). Tugas, Peran, Dan Fungsi Guru Dalam Pendidikan, Jurnal Tarbiyah Islamiyah. 1(1): 88-97

Sugiyono. (2019). Metode Penelitian Kuantitaatif, Kualitatif, Dan R\&D. Bandung: Alfabeta.

Tihul, I. (2020). Eksistensi Guru Sebagai Pribadi Yang Profesional Dan Inspiratif, Jurnal Media Informasi Dan Komunikasi IImiah, Jurnal Media Informasi Dan Komunikasi IImiah, 2 (2):

Triana, R. (2019). Desain Penelitian Al-Qur'an Dan Tafsir, Jurnal IImu Alquran Dan Tafsir, 4(2): 198-215.

Zaini, A. A. (2013). Upaya Guru Dalam Mengembangkan Metode Pembelajaran, Jurnal Ummul Qura, 3(2): 40-48. 